\title{
Entrevista com António Costa Pinto
}

\section{Interview with António Costa Pinto}

\section{Concedida a Angela de Castro Gomes e Francisco Palomanes Martinho Lisboa, 18 de janeiro de 2011}

Estamos no Instituto de Ciências Sociais, em Lisboa, na presença do professor António Costa Pinto, a quem deveremos entrevistar para a revista Estudos Históricos, do CPDOC-FGV. Agradeço a participação de Francisco Palomanes Martinho, meu colega da USP. E a você, António, pela dupla delicadeza de nos receber e nos deixar tratá-lo bem brasileiramente, de você.

- É um prazer. Sou António Jorge Pais da Costa Pinto, nascido em Lisboa, aos 16 dias de setembro do ano de 1953. Meu pai tem um nome muito português, Belarmino Maria da Costa Pinto. Minha mãe, nascida Irene Marinho Pais, ao casar-se com ele incorporou ao seu nome de solteira o apelido Costa Pinto.

\footnotetext{
Angela de Castro Gomes é professora e pesquisadora sênior do CPDOC-FGV, professora titular de História do Brasil da Universidade Federal Fluminense e pesquisadora Al do CNPq (angela.gomes@fgv.br).

Francisco Carlos Palomanes Martinho é doutor em História Social pela UFRJ, professor do Departamento de História da USP e pesquisador do CNPq (fcpmartinho@gmail.com).
} 
Sua família mantinha uma relação quase tradicional com o ideário republicano. Como foi a sua infância nesse ambiente?

- Conheci meu avô paterno já bastante doente e tive pouco contato com ele. A tradição, portanto, me veio principalmente de meu pai, que tinha já 41 anos quando nasci. Meu avô era aquilo a que se poderia chamar de pequeno industrial lisboeta, proprietário de prédios, barbearias, padarias, e pertencia à ala moderada, ou ala dos bonzos, do Partido Democrático, politicamente dominante na Primeira República. ${ }^{1}$ Ele não era um político profissional, mas mantinha intensa atividade social na Baixa, defendendo ideias republicanas. Metido em conspirações, sofreu uma breve prisão a seguir ao golpe de estado, em 28 de maio de $1926,{ }^{2}$ e permaneceu detido 15 dias.

Meu pai licenciou-se em Direito e, na Segunda Guerra Mundial, serviu na tropa acantonada na Ilha da Madeira. Depois, passou a fazer parte da elite da advocacia republicana, antiautoritária e antissalazarista. Tinha amigos comunistas, mas nunca aderiu ao Partido Comunista, ${ }^{3}$ conservando-se, basicamente, republicano e democrata. Aliás, ele escolheu a advocacia porque não pôde ser juiz, barrado que fora por uma interdição da Polícia Política, que não permitia à gente vinda da oposição o acesso à função pública.

Uma espécie de atestado ideológico...

- Esse atestado também existia e era exigido, mas no caso de meu pai bastou que a polícia não aprovasse seu nome, e ele não pode ingressar na carreira da magistratura. Teve de contentar-se com uma profissão liberal. Felizmente, ainda assistiu ao 25 de Abril de 1974, e ainda viveu sob um regime democrático. Meu pai terminou seus dias filiado ao Partido Socialista Português. ${ }^{4}$

O fato de o território de Portugal ser pouco extenso permitia às elites republicanas, antissalazaristas, encontrarem-se na esquina muito facilmente. Mas lá também não estavam as elites favoráveis ao regime?

- Quanto a isso, eu tenho uma visão de historiador e uma visão pessoal. Pessoalmente, entendo que as identidades regionais, sociais e profissionais também eram importantes, o que tornava a convivência de certa forma pacífica. $\mathrm{Na}$ Beira residiam e se relacionavam meu pai, advogado, republicano e antiautoritário, e um juiz conservador, integralista e beato. Davam-se muito bem, evitando, evidentemente, os temas que os afastavam. Por outro lado, é inegável que, a partir do final dos anos 1970, e já na última fase do governo de Marcelo Caetano, ${ }^{5} \mathrm{um}$ pluralismo limitado emergiu.

Já como historiador, eu destaco a habilidade com que o salazarismo cooptou uma parte da elite republicana conservadora, mantendo-a na base de sustentação do regime. Esse dado, mais a estreiteza social das próprias elites, permi- 
tia a convivência. Na realidade, houve apenas dois grandes momentos em que a repressão se intensificou. O primeiro, em 1958 e 1959, ante o desafio de Humberto Delgado, ${ }^{6}$ quando o regime procedeu a um saneamento da administração pública e das forças armadas. $\mathrm{O}$ 'pacto' entrou em crise. Mas é a resistência à Guerra Colonial, nos anos 1960, que vai corroer, progressivamente, o regime. Segmentos dos grupos sociais menos politizados, de classe média urbana, que não pertenciam à oposição tradicional, começam então a olhar para a Europa, e a demarcar-se do regime.

Dá-se, então, uma segunda clivagem. Eram os filhos da classe média que estavam sendo enviados para morrer nessas guerras. Faz lembrar a reação do movimento pacifista, nos Estados Unidos, contra a Guerra do Vietnã. Mas Antônio, financeiramente, sua família sempre esteve bem?

- Nós éramos uma família de classe média normal, e nem a prisão do meu avô alterou absolutamente nada da nossa condição de vida. Ele morreu tarde, e o meu pai, como advogado, conseguiu nos sustentar dentro de um padrão de classe média alta.

Essa história do seu avô era repetida, no círculo familiar?

- Sim. Eu tomei conhecimento dela por intermédio do meu pai. Lembro-me também que existia, em casa, uma versão encadernada d'A história do regime republicano em Portugal, de Luís de Montalvor. Eu li esse livro, um livro de capa dura, por causa do meu avô.

Eram duas histórias: a da República e a do comprometimento familiar com a República.

- Isso mesmo. Vivíamos em luta cultural contra o salazarismo, um contexto no qual se tornava importante revigorar a experiência de períodos democráticos e republicanos anteriores. E não apenas em nossa casa, mas numa boa parte do meio advocatício. Meu pai foi trabalhar para o escritório de Pedro Pitta, ex-ministro da Primeira República, um republicano conservador, ex-bastonário da Ordem dos Advogados. Em Portugal, a advocacia sempre foi uma possibilidade de exercer uma profissão sem depender do Estado. Com isso, naturalmente, muitos republicanos e membros da oposição democrática se tornavam advogados. Mário Soares, ${ }^{7}$ Jorge Sampaio ${ }^{8}$ foram advogados.

Era uma forma de ganhar a vida sem abrir mão de posições antissalazaristas.

- Embora pouco numerosa, e moderada, a elite social nos anos 1940 e 1950 era manifestamente oposicionista. Meu pai, por exemplo, certa vez assinou um self-manifesto, apelando ao ditador para que aproveitasse a sua jubilação, en- 
quanto professor na Universidade de Coimbra, e abandonasse o cargo de presidente do Conselho. Marcava assim uma posição, sem ultrapassar os limites da legalidade do regime. Nas eleições, obviamente não competitivas para a oposição, essa elite exprimia o seu desafeto, apoiando as listas de candidatos sem nenhuma chance, mas contrários à situação vigente.

Essa era a ação possível. E você, ainda jovem, como sentia a força do arbitrio?

- A primeira manifestação que tive disso foi no Colégio Moderno, uma instituição de ensino pertencente João Soares, um antigo ministro da Primeira República e pai de Mário Soares, mais tarde presidente da República. Estudante, eu fui obrigado a vestir a farda da Mocidade Portuguesa - inspirada pelo fascismo dos anos 1930 - e ao voltar para casa, uniformizado, meu pai não achou graça nenhuma; na realidade, ele não gostou nada da ideia, e deixou evidente o seu desgosto, iniciando naquele instante o meu aprendizado do socialismo. Mais tarde, eu me situei politicamente, bem mais à esquerda que o meu pai...

Antes, gostaríamos de perguntar se a família da sua mãe também tinha a mesma tendência republicana.

- A família dela, sim, embora ela própria, por sempre ter sido muito católica, tivesse uma imagem da Primeira República marcada pelo salazarismo. O medo da desordem e da violência política tornaram-na mais conservadora.

Mas você teve educação católica, fez a primeira comunhão?

- Tive educação católica. Depois da experiência no Colégio Moderno, meu pai, apesar de republicano, enviou-me para um colégio católico, interno, mas de orientação pedagógica liberal, em Portalegre, no Alto Alentejo. Mais tarde, estudei no Liceu Pedro Nunes, em Lisboa, que, conforme a tradição portuguesa dos liceus, abria algumas matrículas para alunos oriundos das classes populares. Mas a maior parte era mesmo da classe média alta. A turma em que me formei, já prestes a entrar para o curso de Direito, tinha muitos filhos de ministros de estado. Foi justamente quando aderi a uma incipiente militância política contra a ditadura.

Do ponto de vista do convívio familiar foi duro. Bastante duro. Em contrapartida, ganhei liberdade e pude desfrutar melhor a sociabilidade dos anos 1960. Por exemplo, eu recebia uma revista, Vida Mundial, e dentro do colégio tínhamos jornais onde de alguma forma nos permitiam contestar a Guerra do Vietnã. Curiosamente, os colégios católicos tinham autonomia em relação à ditadura: não éramos obrigados a frequentar a organização oficial da juventude, desde que optássemos pelo escotismo. 
E você, é claro, preferiu ser escoteiro?

- Para escapar da Mocidade Portuguesa, o escotismo era bem melhor, e acabou por ser uma experiência interessante.

Mas sua militância se iniciou-se no Liceu.

- Regresso ao Liceu e a Lisboa em 1968, com o movimento estudantil em plena agitação; a crise de Coimbra ${ }^{9}$ ocorre em 1969, e aí eu entro para o Movimento Associativo dos Estudantes do Ensino Secundário, participando da primeira tentativa de greve no liceu. Rapidamente, ingresso na União dos Estudantes Comunistas Marxistas-Leninistas, uma organização de extrema-esquerda.

Um tio seu fora comunista, não é?

- Carlos Alberto Blasco Gonçalves. Faleceu há pouco. Ironicamente, era militar profissional e, na Guerra Colonial, desempenhou várias comissões em África. Foi ele quem me introduziu na literatura marxista. Li Plekhanov e Politzer em traduções do português brasileiro, da Editorial Vitória, ${ }^{10}$ uns livros grossos, com capas de cores fortes, verde escuro, vermelhão, vendidos nas livrarias de Portugal meio às escondidas nos anos 1960. Com certeza datavam de antes da ditadura militar no Brasil... Chegaram às minhas mãos entre 1967 e 1968.

Meu tio alcançou o posto de tenente-coronel. Nascido no Alentejo, região tradicionalmente de esquerda, esteve na Índia Portuguesa pouco antes da descolonização. Primeiro foi simpatizante, depois filiado no Partido Comunista. Deu treinamento aos membros do MPLA ${ }^{11}$ na primeira guerra civil angolana, após a independência.

Ou seja, você estava à esquerda do PCP.

- A essa altura, sim. A União dos Estudantes Marxista-Leninista era um 'partido' que resultara da cisão à esquerda liderada por Francisco Martins Rodrigues, do PCP, vinculado aos PCs da Albânia e da China, e que após o 25 de Abril vai se unir a outros grupos para constituir a União Democrática Popular (marxista-leninista), e, depois da transição, o chamado Partido Comunista Português Reconstruído, ${ }^{12}$ que elegeu um deputado no Parlamento. Todo esse processo transcorreu sob forte influência de Diógenes Arruda, do Partido Comunista do Brasil. $^{13}$

Nesse período você ainda era secundarista?

- Perfeitamente, estudante do ensino secundário. Mas por questões de militância política já fazia outros estudos com vistas a entrar para a Faculdade de Economia; isso era importante para a organização. Quando se dá o 25 de Abril, 
eu estou prestes a terminar o ensino secundário, tardiamente, sim, porque eu me dedicava muito mais à militância.

No Liceu, havia muitos alunos de famílias adeptas do regime salazarista?

- Muitos, não. E convém não esquecer que desde 1968, com a morte política - não física - do ditador Salazar, ${ }^{14}$ e o seu afastamento, Marcelo Caetano assume o poder, e isso inaugura uma fase de relativa liberalização. Pelo menos, no início. Por outro lado, os liceus têm uma clientela de classe média, que a ditadura não se preocupa tanto em reprimir. Há estudantes presos, é claro, mas, ao mesmo tempo, o governo toma algum cuidado com o movimento estudantil. Em consequência, a oposição predomina, seja de extrema-esquerda ou de comunistas e mesmo alguns próximos do trotskismo. As elites estudantis em bulício abrigam todas essas tendências. De outra parte, existem pequenos núcleos de estudantes de extrema-direita que já se demarcam, inclusive, de Marcelo Caetano, embora o considerem razoavelmente liberal. A grande massa, evidentemente, permanece apática, como é natural em um regime autoritário.

E os professores, António?

- O corpo docente também era pluralista. Havia menos controle, e professores que, sem se manifestarem, não hostilizavam quem atuava politicamente. Dotados de formação universitária, alguns viam até com simpatia os engajamentos de esquerda. Nos anos 1960, o ensino secundário se massificou, e a Guerra Colonial politizou numerosos segmentos da classe média, que se voltam contra o regime. Muitos licenciados exilam-se, para escapar do serviço militar. Portanto, já estamos a viver um momento de maior ebulição.

O serviço militar era obrigatório inclusive para quem estava cursando faculdade?

- Eram 4 anos de serviço, que podiam ser adiados até o final da licenciatura, caso não se chumbasse, quer dizer, fosse reprovado. No meu caso, eu entrei na universidade pouco antes do 25 de Abril; só cumpri a obrigatoriedade depois da queda do regime. Não fosse assim, eu provavelmente teria buscado o exílio, porque três meses antes a prisão de duas pessoas, que poderiam denunciar a mim e a um colega meu, nos forçou à clandestinidade. $\mathrm{O} 25$ de Abril me devolveu à legalidade, a uma vida normal.

Como era a militância dos estudantes radicais? O que eles faziam? O que você fazia?

- Os anos 1960, em Portugal, são muito matizados. De um lado, temos os filhos da classe média, no liceu, experimentando drogas leves e adotando uma postura neopacifista. Paralelamente, as pequenas organizações de extrema-esquerda, na clandestinidade, se pautam por uma ética moralmente conservadora 
e pelo mito leninista do revolucionário profissional. Nós tentávamos controlar o Movimento Associativo do Ensino Secundário através do Intervalo, o jornal da entidade, publicado legalmente, ao mesmo tempo em que editávamos, clandestinamente, o Servir o povo, órgão da União dos Estudantes Comunistas, destinado ao recrutamento e à criação de núcleos de simpatizantes. Também organizávamos convívios de politização e ensaiávamos movimentos de protesto anticoloniais, por meio de manifestações clandestinas contra o regime. Além disso, consumíamos um tempo imenso em discussões ideológicas com as demais tendências...

Imaginamos que deviam ser muitas... Muitas mesmo, como no Brasil.

- A tendência à pulverização é clássica. Duas ou três organizações se definiam como marxistas-leninistas, e uma ou duas se intitulavam trotskistas. Somando os comunistas e os católicos de esquerda, não faltava polêmica no interior do movimento secundarista.

Mas como é que você entra na faculdade se está clandestino?

- Na prática, não entro, justamente porque estou clandestino. Fiz a tropa, a recruta, durante o processo da transição democrática. A tentativa de golpe de Estado dos moderados, em 25 de novembro de 1975, ${ }^{15}$ bloqueia as tendências revolucionárias, e eu sou saneado das Forças Armadas - eu e muitos. Enfim, volto à minha vida normal, salvo seja! E aí, sim, em vez de ir para escola de Direito, decido fazer o curso de História.

\section{A sua ida para o quartel foi determinação do partido? Você vai para o quartel fazer} política?

- Na verdade, essa decisão derivou de eu estar prestes a chumbar um ano, sem condições, portanto, para propor um adiamento do serviço militar, que por outro lado já não me convinha, pois, em 1974 e 1975, era importante ingressar nas Forças Armadas, onde mais se fazia política. Em 1975 fui indicado para o comando e passei a controlar os vários militantes que também faziam a recruta, infiltrados tanto como eu.

Quer dizer que você nunca chegou a fazer o curso de Direito? E por que História?

- Nunca terminei Direito. Já História, fiz o curso todo, porque me interessavam as Ciências Sociais. Porque já me sentia algo desencantado da militância política... Porque não me apeteceu suceder ao meu pai, enquanto advogado... Foram vários motivos. Na ocasião, a única alternativa era Sociologia - Ciência Política ainda não existia - e História era um curso que estava em plena mudan- 
ça. Portanto, em dezembro de 1975 - ao abrigo da lei militar, podíamos entrar no meio do ano - comecei a cursar História, na Faculdade de Letras da Universidade de Lisboa. O que eu encontro? Uma revolução! Os professores conservadores, do Departamento de História, estavam afastados ou tinham sido depurados, saneados...

\section{Foi rápido assim?}

- Logo a seguir do 25 de Abril. Não restou nenhum dos antigos catedráticos, alguns renomados, como Jorge Borges de Macedo. ${ }^{16} \mathrm{O}$ Departamento de História estava sob a direção de um comitê de mestres e alunos, uma gestão considerada anárquica até por muitos que haviam feito oposição à ditadura, que acabaram saindo, para fundar a Faculdade de Ciências Sociais e Humanas da Universidade Nova. Os professores, às vezes, eram recrutados por concurso. Os exilados voltaram. Um deles, Joaquim Manoel Godinho Braga Barradas de Carva1 ho, ${ }^{17}$ lecionou na Universidade de São Paulo e na École des Hautes Études, na Sorbonne. Borges Coelho, ${ }^{18}$ medievalista, ainda é membro do Comitê Central do PCP. Grande número de cadeiras optativas surgiu naquela ebulição revolucionária que resultou em uma remodelação geral dos cursos. Metade das matérias versava sobre sociologia da literatura, economia política... O curso tornou-se interdisciplinar.

\section{E qual era a base da historiografia portuguesa naquela época?}

- Moderna e medieval, seguindo a grande tradição. Porque durante a ditadura, a história contemporânea esteve praticamente ausente do ensino. $\mathrm{Na}$ minha geração, alguns colegas desencantados politicamente dedicaram-se aos períodos recuados, à expansão etc. Propenso às ciências sociais, eu tratei de produzir ensaios sobre questões mais recentes desde o primeiro ano da faculdade.

Foi a política que o conduziu à investigação do que então se chamava de história contemporânea.

- Exatamente. Mas em 1975, ainda muito dominado por Poulantzas, Althusser, autores que estavam no auge, em Portugal, eu me guiava por uma hiperteorização marxista. Lembro-me de alguns exilados brasileiros: Valentina da Rocha Lima e Pedro Celso Uchoa Cavalcanti. Havia um terceiro, Fernando António Novais, afro-brasileiro, que lecionava Teoria da História. A maior parte do corpo docente universitário era constituída por professores assistentes, sequer doutorados, visto que o doutoramento, em Portugal, restringira-se à elite catedrática, que fora saneada. 
Com a formação incompleta deviam ser muito jovens ainda...

- Rupturas, como a que estávamos vivendo, produzem situações curiosas, irônicas mesmo. Assim, quando termina a transição e instaura-se o processo de regularização, os bons alunos são convidados e se tornam monitores. Aconteceu comigo, com Nuno Monteiro, ${ }^{19}$ Bernardo Vasconcelos e Sousa, ${ }^{20}$ Pedro Tavares de Almeida ${ }^{21}$ e outros, que a partir do terceiro ano, na metade do bacharelado, já ajudávamos os professores. O dado interessante, porém, é que nenhum de nós lá ficou. Quando o poder hierárquico se recompôs, na Faculdade de Letras, o Departamento de História caiu nas mãos de professores de má qualidade, o que fez com que se tornasse o mais fraco das universidades portuguesas. Um desses professores era mais literato do que propriamente historiador. Outro, formado em Moçambique, não era uma pessoa arrogante, mas totalmente inexistente, do ponto de vista intelectual.

Ao longo dos anos 1980, todos nós deixamos a monitoria, tentando encontrar posições em outras universidades. Isso já não tinha a ver com política, mas com dimensões universitárias que não levam em conta critérios de esquerda e direita. Eu deixara de ser um militante... Aliás, a realização que alcancei no curso de História me distanciou da política. Passei a entender que a História não era uma área de politização, pertencendo à esfera das ciências sociais e humanas. Políticos não precisam ser professores de História, e vice-versa.

E que professores foram importantes para você?

- Muitos dos que foram importantes hoje são meus colegas. Tive uma excelente professora de Antiguidade Clássica; de nacionalidade russa, ela era esposa de um exilado português. Borges Coelho lecionava História Medieval. Mas aquele com quem mais convivi talvez tenha sido Barradas de Carvalho. Não tanto pela sua obra historiográfica - mais referente à expansão - e sim por sua força intelectual. Íamos ao Bairro Alto, de Lisboa, jantar com ele, que gostava muito do contato pessoal conosco. Frequentemente nos reuníamos em uma tertúlia ao seu redor.

Na USP, Barradas de Carvalho mantinha-se como uma referência; amigo do Sérgio Buarque de Holanda, ele foi o orientador de tese de doutorado do Boris Fausto. O marxismo tinha muito peso na universidade brasileira, uma tradição forte, particularmente na USP. Existia um grupo que se reunia para ler O Capital...

- Outro grande professor, quase da minha idade, foi José Manoel Sobral, ${ }^{22}$ que ingressara na carreira mais cedo; por estar na política, demorei um bocadinho até sair do secundário. Atualmente, Sobral é um dos pesquisadores do ICS - Instituto de Ciências Sociais. 
Essa sociabilidade intelectual tão intensa produzia alguma discussão acerca da historiografia brasileira?

- Curiosamente, com o 25 de Abril fecha-se a cadeira de História do Brasil. Se bem me lembro, estava a cargo de Veríssimo Serrão; ${ }^{23}$ ele foi saneado... Durante o meu período na faculdade, não havia nenhum estudo formal de História do Brasil, nem da América Latina.

E que contorno tem o ICS na época da sua transferência para lá?

- O ICS era considerado a instituição de pesquisas mais avançada do país. Tinha mais recursos e funcionava à base da meritocracia, uma inovação que partiu do Ministério da Ciência e Tecnologia e significou uma revolução silenciosa na pesquisa histórica em Portugal. O clientelismo foi posto de lado, deu-se mais a voz à competência. Hoje em dia, esse Ministério está vinculado às universidades, e atua através da Fundação para a Ciência e a Tecnologia, cujo primeiro diretor foi Mariano Gago. O número de bolsas para os cursos de História cresceu, assim como o número de pós-doutorados.

\section{E concursos também, António?}

- Menos, devido ao peso da austeridade do nosso sistema universitário. O que aumentou também foi o emprego precário de pesquisadores, professores... Os contratos de cinco anos. Mas, sem dúvida operou-se uma transformação muito grande no panorama da pesquisa histórica. Portanto, minha passagem para o ICS significou uma oportunidade de trabalho em bases mais interdisciplinares.

$\mathrm{Na}$ Faculdade de Letras, somente graças aos estudos de história e literatura, os alunos mais criativos conseguiam abrir novos horizontes. Eu fiz trabalhos, em sociologia da arte, sobre os muralistas mexicanos e o conteúdo social da sua arte. Uma escolha que decorreu, evidentemente, da minha formação marxista. Já as ditaduras brasileiras surgiam ao estudarmos o movimento operário, o que era consequência do retorno ao tema, não à região geográfica. E o convívio com o Barradas de Carvalho sempre trazia à baila assuntos brasileiros. Além disso, a escola dos Annales tem essa marca interdisciplinar característica das ciências sociais francesas, da sua relação com o Brasil; Lévi-Strauss era parte obrigatória das cadeiras de Antropologia e História ou História e Literatura...

Mas que livros brasileiros você lia?

- Bem, naquela época, eu não poderia ser considerado o protótipo do estudante de história. É importante salientar isso. Nossa curiosidade advinha da prática política, da proximidade com o Partido Comunista do Brasil. A maior parte dos livros brasileiros haviam sido importados antes do 25 de Abril. Jorge Amado será, talvez, a fonte original mais rica do meu conhecimento acerca da so- 
ciedade brasileira. Lera também alguns romancistas portugueses, um deles ambientados no ciclo da borracha... Tudo literatura.

Nada de historiografia ou da área das ciências sociais?

- Não. Só me dediquei a essas leituras mais tarde, principalmente por influência de Barradas de Carvalho, e um pouco por sugestão de Fernando Novaes, ${ }^{24}$ colega de faculdade. Então, li muito sobre o Brasil Colônia, o Antigo Regime, pouca coisa, porém, sobre o Brasil contemporâneo. Só mais tarde, já como monitor, terminada a licenciatura, mas ainda sem lecionar, desfrutando de maior autonomia, portanto, e por indicação de Gino Germani, iniciei estudos sobre o fascismo de Vargas e de Perón...

Você já tinha saído da faculdade?

- Saí em 1981, estava a transferir-me, como assistente estagiário, para o ISCTE - Instituto Universitário de Lisboa. Nessa época são os sociólogos e cientistas sociais, mais do que os historiadores, que vão se debruçar sobre os temas contemporâneos, e escrever a respeito. Entre as grandes distribuidoras destacam-se a Editora Zahar, com uma enorme produção marxista, obras de Lenin, Gramsci; a Universidade de Brasília; e a Difel, cuja coleção Corpo e alma do Brasil eu comecei a ler muito cedo. Concentrado em história política e contemporânea, fascismo, os anos 1930 etc., a única referência que encontro é um trabalho de Hélgio Trindade, publicado no início dos anos 1980, sobre a Ação Integralista Brasileira.

Na coleção Corpo e alma do Brasil, publicou-se um livro, Brasil em perspectiva, obra coordenada por Carlos Guilherme Mota, muito importante à época.

- Meus colegas, dedicados ao estudo do Antigo Regime, mantinham contato direto com pesquisadores no Brasil; eu, ao contrário, comecei a ler literatura brasileira nas bibliotecas americanas. Porque a história contemporânea do Brasil, de Portugal e da Argentina é, de fato, uma história comparada. Até os anos 1970, não há nenhum vínculo particular com Portugal.

No Brasil, deu-se o mesmo: a História contemporânea só vai ser produzida a partir da década de 1970. Antes, não existe praticamente nada. Quando eu, Angela, me formei na UFF, em 1969, não se passava da Revolução de 1930.

Mas, António, você se referiu ao início da monitoria... Por que você escolheu o Instituto de Lisboa?

- Conforme relatei, no final dos anos 1970, houve uma verdadeira fuga em massa da Faculdade de Letras. Uns escaparam para a Universidade Nova de Lisboa, a fim de trabalhar com Victorino Magalhães Godinho... ${ }^{25} \mathrm{Eu}$ fui para $\mathrm{o}$ 
Departamento de História do ISCTE, trabalhar sob a direção de Miriam Halpern Pereira, ${ }^{26}$ cujos contatos com pesquisadores brasileiros me propiciaram novos relacionamentos. O ambiente lá era mais aberto, cosmopolita, facilitando a integração de historiadores doutorados em França, e influenciados pela escola dos Annales.

Você se referiu à Universidade Nova, formada por professores que haviam se afastado da Universidade de Lisboa...

- A Universidade Nova fazia parte de um programa modernizador do último ministro da Educação da ditadura, Veiga Simão, para aprimorar a formação das elites em Portugal. Ocorre que a maioria das suas faculdades só foi criada após o 25 de Abril. José Matoso sai do Departamento de História, da Faculdade de Letras, para a Universidade Nova. Outros seguem o mesmo caminho. E, mais tarde, muitos da minha geração acabam por entrar também na Universidade Nova, como assistentes.

Inclusive vindos do ISCTE e do ICS?

- O ISCTE é uma escola de Ciências Sociais, e o ICS, um centro de pesquisas. Ambos tiveram o mesmo pai fundador, Adérito Sedas Nunes, ${ }^{27}$ havendo muita proximidade, portanto. À minha chegada, embora ainda fôssemos poucos, as mulheres constituíam maioria e estavam a se doutorar em universidades francesas. Miriam Halpern Pereira tinha se doutorado na École des Hautes Études.

Havia muita gente jovem, sem dúvida. Basta dizer que durante bastante tempo não tivemos mais do que uma catedrática. Além disso, dado que se tratava de uma escola em crescimento, nos relacionávamos com outros departamentos, como Sociologia e Antropologia...

\section{Você leciona o quê?}

- Fui para o ISCTE dar aulas de História Contemporânea Europeia. Minha tese de mestrado compunha-se de uma parte de pesquisa sobre um movimento de extrema direita dos anos 1920, em Portugal, e uma dissertação sobre metodologia da história oral.

\section{Mesmo?! Que interessante!}

- No início dos anos 1980, essa metodologia estava em pleno desenvolvimento na Europa, tanto que se criara uma Associação de História Oral. Lecionando história contemporânea, pareceu-me extremamente importante utilizar fontes orais, e eu quis reforçar a minha competência. 
Você utilizou fontes orais na sua pesquisa de tese?

- Apenas como complemento. Entrevistei cerca de doze antigos fascistas, militantes de extrema direita. Já os encontrei idosos e quase todos doentes. Posteriormente, para a minha tese de doutoramento sobre o Nacional-Sindicalismo ${ }^{28}$ em Portugal nos anos 1930, consegui localizar muitos deles.

Mas você publicou um trabalho antes da graduação...

- Prestes a sair da faculdade. Chama-se $A$ Ação Escolar Vanguarda, uma organização de caráter semioficial da juventude fascista. A dissertação de mestrado versou sobre a Liga 28 de Maio, uma organização de extrema direita.

Por que a opção de estudar a direita?

- Bem, a motivação intelectual originou-se da minha própria vivência durante os últimos anos do regime ditatorial e, a seguir, o processo de transição por ruptura, a revolução portuguesa, a crise de Estado etc. Era natural que os meus interesses acadêmicos se concentrassem no autoritarismo e na mudança. Pertencíamos a um pequeno núcleo de jovens mais velhos, eu, Francisco Bettencourt e outros, que tínhamos já desempenhado atividades diversas. Por isso que começamos a publicar mais cedo. Quando $A$ Ação Escolar Vanguarda foi lançada, eu estava cursando o $5^{\circ}$ ano da faculdade.

Convém também não esquecer que, nessa altura, entre o final dos anos 1970 e o início dos anos 1980, nem existia o mestrado. Havia algo equivalente, uma espécie de prova de produção da carreira. Em Portugal, para o ingresso na carreira universitária, como assistente estagiário, exigia-se uma licenciatura; com o mestrado, nos tornávamos assistentes; e só graças ao doutoramento podíamos ascender ao cargo de professor assistente.

Mas a conclusão da licenciatura e esse trabalho tiveram algum peso...

- Um peso razoável. Mais tarde, professores conservadores valeram-se disso para aplicar uma estratégia protecionista e negar a equivalência de graus àqueles que vinham, por exemplo, com teses produzidas em universidades da Inglaterra, ou dos Estados Unidos, ou mesmo com o doctorat de troisième cycle, concluído na França. Eles diziam que nos faltavam requisitos...

Enfim, é nesse periodo mais inicial que você se torna professor do ISCTE, para lecionar História Europeia do século XX.

-E a história contemporânea de Portugal também. Primeiro como assistente de Miriam Halpern Pereira, durante um ano, e aí, sim, tive que abranger os séculos XVIII e XIX. Mas minhas aulas sempre foram acerca do século XX. 
Na prática, como era essa proximidade entre o ISCTE e o ICS?

- Conviviam bem, até que começaram a crescer, e, então, distanciaram-se. O ICS enquanto centro de pesquisa e o ISCTE convertido em universidade, atualmente uma universidade na área das Ciências Sociais. Havia muitos pesquisadores do ICS que lecionavam no ISCTE. Eu mesmo comecei dando aulas no ISCTE, antes de me tornar pesquisador no ICS. Até certa altura, existiu um convívio harmonioso. Mas foi justamente a Sociologia, a nossa disciplina mãe, que gerou tensão e acabou nos separando. A história contemporânea era bem aceita, mas com o pós- 25 de Abril adquiriu uma visibilidade enorme, e polarizou o interesse de um número significativo estudantes, que ocupou o espaço público, lançando-se na luta pela memória da sociedade portuguesa...

\section{A demanda chegou a criar disputa de espaços?}

- Isso. A conquista da história contemporânea foi obra de historiadores, sociólogos e cientistas políticos, mas já no início dos anos 1980 eram estes últimos que predominavam com trabalhos sobre as origens católicas do salazarismo e sobre o corporativismo. Homens como Manuel Braga da Cruz, ${ }^{29} \mathrm{Ma}-$ nuel de Lucena ${ }^{30}$ e outros, que tomaram a frente dos historiadores. Eu sou dessa geração que irrompe nesse momento e força os debates sobre a natureza do regime, fascismo ou não fascismo, contribuindo decisivamente para estruturar a área ao longo dos anos 1980. De início, nos confrontamos com outras disciplinas, inclusive com a ciência política. Porém, progressivamente, os sociólogos e os cientistas políticos abandonaram estes temas, que ficaram por conta dos historiadores.

No Brasil, o processo é similar. E como era ser historiador trabalhando com o tempo presente no Portugal dos anos 1980?

- Sem dúvida, houve alguma resistência da comunidade historiográfica, uma vez que a fronteira entre a história contemporânea e o jornalismo histórico é realmente tênue. Por outro lado, a influência dos Annales, sempre muito marcante na historiografia portuguesa, inclusive na sua renovação após a transição democrática, remetia à época medieval. A historiografia contemporânea, portanto, só mantinha pontos de referência metodológicos com a escola francófona nos campos da história econômica e social.

Por isso é que vão se engendrar dois grandes movimentos. Uma história política, que busca referências na sociologia e na ciência política, e a chamada nova história econômica, que, aos poucos, começa a apontar para modelos mais quantitativos, à revelia da história econômica e social de matriz francófona. Dá-se que também existia aquilo a que, no Brasil, se chama de demanda social. E 
a minha admissão, por assim dizer, ocorre justamente quando a demanda social por história contemporânea se intensifica. Como consequência, temos acesso à imprensa, resenhas publicadas nos jornais, mais facilmente do que os colegas dedicados à história medieval ou à história moderna.

Isso é bom, mas frequentemente paga-se um pedágio...

- Claro. No entanto, não sei com que se afligem os brasileiros, mas em Portugal, o grande dilema do historiador contemporâneo é a ilusão da transparência, e o seu pior resultado: uma formidável acefalia metodológica interpretativa. Os que se dedicam a outras áreas não correm tanto esse risco.

Às vezes, nem se considerava que era história o que a gente fazia. Agora, António, conte-nos acerca da sua pós-graduação.

- O ISCTE, para mim, foi fundamental. Enquanto os colegas estavam a fazer doutoramentos fora - a maior parte em França -, eu permaneci longe da historiografia dos Annales e próximo de uma dimensão mais interdisciplinar. De fato, havia uma pequena comunidade a produzir estudos sobre Portugal. Alguns, ironicamente, eram cientistas políticos que faziam estudos sobre o Brasil. A transição os faz descobrir o meu país. Um dos primeiros é Philippe Schmitter, ${ }^{31}$ que pesquisava as políticas dos interesses organizados brasileiros nos anos 1960 e, antes mesmo do 25 de Abril, vem atrás do corporativismo português.

Nessa época ele já se tornara um autor clássico na área dos estudos do corporativismo, com o texto Ainda o século do corporativismo, numa alusão ao livro de Manoilesco.

- Ele é dos primeiros a refletir sobre a transição portuguesa para a democracia. Focado no regime autoritário, aproximei-me de Schmitter e lhe disse que cogitava fazer o doutoramento no Instituto Universitário Europeu, onde ele lecionava. Tratava-se de uma instituição internacional e transnacional, com estudantes oriundos de todos os países do continente. Acontecia o mesmo em algumas universidades da Inglaterra e em uma ou duas da França...

Enfim, isso me abriu os olhos para uma história comparada, e comecei a pensar, como temas de pesquisa, no autoritarismo, na transição para a democracia, na existência da Europa do Sul, uma região tão carente de mudanças. Foi uma oportunidade para desacelerar e ler. Os seminários do doutorado eram bastante livres, e de uma diversidade temática extraordinária, versando sobre os movimentos sociais femininos, no século XX, história das ideias políticas e teoria política, mudança social etc. 


\section{Schmitter foi seu orientador?}

- Não. Naquela ocasião, em plenos anos 1980, ele estava na Universidade de Stanford. Meu orientador foi um historiador britânico, Stuart Woolf, autor de textos interessantíssimos sobre o fascismo e o nazismo. Frequentei os seminários dele. Também tive contato com a rica historiografia italiana, e assisti aos debates entre Renzo De Felice e Nicola Tranfaglia sobre a natureza do fascismo. Estive em conferências nos Estados Unidos, onde conheci Robert Levine e Stanley Payne. Sim, eu ainda era um estudante de doutorado, porém numa faixa etária bem mais alta que a média dos meus colegas.

Nós estamos tentando demarcar a trilha que você seguiu, sem abandonar a metodologia da história oral. Como a história oral é forte na Itália, também, queríamos saber se ela suscita alguma curiosidade em você, nesse período da pós-graduação?

- Sim. Mas meu interesse pela história oral é anterior e, curiosamente, procede dos catalães, Philippe Joutard e Mercedes Vilanova. O que aprendi com eles data de 1982 ou 1983, antes da minha ida à Florença.

Na Itália, a historiografia que usa a metodologia de história oral tem uma produção importante ligada à memória do fascismo.

- Claro! Luisa Passerini: Torino operaia e fascismo é a sua primeira obra. Não abandonei, inclusive, porque entendo que a história é a projeção das metodologias das ciências sociais a áreas do passado. E, hoje em dia, não mais se pode reconhecer o manuscrito como a única fonte de ciência histórica; às vezes, ela brota de fontes exclusivamente orais, ou exclusivamente escritas, ou orais e escritas.

Sua experiência em Stanford foi uma grande mudança?

- Mudei-me para Stanford no terceiro ano do doutoramento, e aí, curiosamente, tomei conhecimento da obra de estadunidenses especializados em América Latina, inclusive contatando vários deles pessoalmente. Estive com Levine em um colóquio sobre populismo e corporativismo que ele organizou na Associação Americana de História. E é nesta época que começo a ler obras que tratam do Estado Novo brasileiro, o regime de Vargas, a Ação Integralista Brasileira etc. Não pensava, até então, em aprofundar pesquisas a respeito, muito menos em algum tema brasileiro específico. Estava mais a discutir, com o já mencionado Hélgio Trindade, católicos brasileiros impressionados pelo fascismo... Enfim, andava à volta desse universo dos anos 1930, no Brasil. Pois não foi nas bibliotecas portuguesas, mas nos Estados Unidos, que fui ler a historiografia 
brasileira, já em 1987 e 1988. Tarde, talvez, descobri seu livro, Angela, A invenção do trabalhismo.

Muito obrigada. O livro teve sua primeira edição em 1988, pois foi minha tese de doutorado. Mas, António, você chegou a manter contato com historiadores latino-americanos, argentinos?

- Não. Eu conhecia as obras. Lia a Luso-Brazilian Review, onde vários historiadores brasileiros e brasilianistas publicavam artigos. E comparecia a congressos, durante os quais estabeleci relações com latino-americanistas. Mas isso já nos anos 1990.

Terminada a pós-graduação você retorna ao ISCTE?

- Sim. Nessa ocasião, em virtude da temática dos meus trabalhos, estreitei os vínculos com cientistas políticos. Uma das minhas referências no estudo sobre as ditaduras era Juan Linz. Essa tendência consolidou-se quando iniciei meu estudo da transição democrática. Se, em Portugal, eu recorria mais aos historiadores, a literatura que eu consultava com relação a outros países era em geral de cientistas políticos.

Eu, Angela, também fiz a minha pós-graduação em ciência política no IUPERF, sem deixar de ser historiadora; trabalhava com a ciência política por ser uma forma de fazer história política contemporânea. Naquele momento, a historiografia brasileira ainda não acolhia bem os temas contemporâneos. Até hoje isso não está inteiramente superado, embora tenha melhorado enormemente...

- No tocante ao Brasil, eu estava em contato com historiadores da Universidade de Brasília, especializados em relações internacionais. Mantínhamos um colóquio em torno de Amado Cervo. Todavia, os primeiros projetos só se concretizaram na segunda metade dos anos 1990.

O ano de 1988 é o da nossa Constituição, e na década de 1990 multiplicam-se os programas de pós-graduação. É um período riquíssimo para a historiografia brasileira. Em paralelo, cresce o interesse por Portugal. Ocorreu o mesmo no campo historiográfico português?

- A partir da segunda metade dos anos 1980, a historiografia portuguesa se volta para o Estado, tentando repensá-lo, e a própria identidade nacional. Há um ajuste contas com a velha historiografia, não apenas conservadora, mas tradicionalista. Paralelamente, aqueles que já trabalhavam com a história moderna desde o início da década fazem um grande esforço para repensar o Estado português pós-independência do Brasil e as relações luso-brasileiras, para além das 
narrativas clássicas. Nesse particular, destacam-se Valentim Alexandre ${ }^{32}$ e Miriam Halpern Pereira. Numa terceira dimensão, da qual eu participo mais, tenta-se avaliar o impacto da adesão de Portugal à União Europeia ${ }^{33}$ e a descolonização do Império português. A resistência e a descolonização talvez sejam as marcas mais fortes da transição portuguesa para a democracia. Enfim, nos últimos anos, são estas três dimensões que têm moldado a pesquisa historiográfica em Portugal.

Esses movimentos provocam algum aumento do interesse pela historiografia brasileira?

- Sem dúvida. A transição democrática portuguesa atrai vários cientistas sociais, alguns exilados brasileiros. Além disso, a cultura política de massas, a partir dos anos 1970, com destaque para as novelas, acarreta uma grande massificação da cultura midiática, em Portugal, produzindo uma redescoberta do Brasil pela sociedade portuguesa, e da economia brasileira pelas elites, em particular. Ironicamente, esse movimento se inicia pela via da Sociologia e da Antropologia. Por que? Porque os Congressos Afro-Luso-Brasileiros permitiam que os contatos se mantivessem mesmo antes da transição democrática. Os historiadores contemporâneos foram os últimos a chegar.

Concordamos. No Brasil deu-se o mesmo, impondo aos historiadores, chamados hoje de historiadores do tempo presente, um duplo desafio: constituir e constituir um lugar no campo historiográfico.

- Os historiadores, tanto brasileiros como portugueses, que estudam o período colonial, têm muito maior propensão para pesquisar no Brasil e em Portugal. Basta consultar as estatísticas da Anpuh para verificar, por exemplo, a quantidade de historiadores portugueses que trabalha com Brasil Colônia. Já no caso da Anpocs, das ciências sociais, acontece outra coisa: há um maior equilíbrio entre brasileiros em Portugal e de portugueses no Brasil.

Quem estuda a Colônia, no Brasil, precisa vir a Portugal para pesquisar as fontes históricas.

- Exato, ao passo que as fontes da história contemporânea brasileira encontram-se no Brasil. Porém, o desafio da história comparada é muito mais interessante.

Qual o seu prognóstico para este intercâmbio?

- Eu imagino que será cada vez maior. Em parte, reconheçamos, porque existe uma ligação histórica entre os dois países, e porque o Brasil está em vias de se transformar em uma potência regional, que de certa maneira já é. O sistema 
universitário e os fundos de apoio à pesquisa são maiores, no Brasil, e isso também tem muita importância. Em Portugal, nos últimos 15 anos, temos crescido, mas menos. Por outro lado, o cruzamento das comunidades de ciências sociais e de história amadureceu, tornou-se mais cosmopolita. A ideologia de pequenez ou paroquial, que predominava nas elites de outrora, foi superada. Superamos, também, a ideia de que a sociedade brasileira nos devia o reconhecimento acerca da grande importância de Portugal. Os professores mais velhos se agarravam a isso. Ora, o Brasil contemporâneo já pouco tem a ver com as Misericórdias da Bahia. Ou seja, os historiadores do contemporâneo já não têm nada a ver com isso!

António, como professor, você nota maior interesse pelo tempo presente por parte dos jovens pesquisadores portugueses? No Brasil, são cada vez mais numerosos os estudos sobre o período da ditadura civil e militar e da transição para a democracia.

- Em Portugal existe uma grande apetência pelo tempo presente, conquanto a comunidade historiográfica se fixe em temas muito particulares. Por exemplo, são poucos os estudos comparativos entre Portugal e Espanha, que fica bem ao nosso lado. História comparada é difícil de fazer. Não é fácil convencer um aluno meu a ir ao Brasil, pesquisar fontes primárias da história luso-brasileira.

Em outras áreas, não há tanta dificuldade em aceitar essa ideia. Em que pesem as mudanças ocorridas, $\mathrm{o}$ ambiente das nossas faculdades é por vezes mais fechado do que eu gostaria que fosse. O que se mudou não foi suficiente. Pode parecer pessimismo, mas imagino que devo receber muito mais estudantes de doutoramento vindos do Brasil do que os colegas brasileiros estarão recebendo estudantes portugueses do mesmo nível. E não apenas pelo fato do seu país ser muito maior e mais populoso...

Há aí uma questão de escolha; de tradição historiográfica mesmo.

- Existe uma propensão a não sair do lugar, a pensar pequeno. Por exemplo, amanhã, vou estar com uma aluna que inicialmente pretendia elaborar uma tese sobre imigração, comparando Portugal à Espanha, mas já me está a querer estudar a imigração em Viseu...

Talvez a pesquisa na França ou nos Estados Unidos pareça mais atraente aos estudantes do que no Brasil...

- No que diz respeito à história moderna, sim, mas quanto à história contemporânea, vejo os estudantes ainda fechados, indiferentes aos desafios dos professores e às melhores condições das bolsas. Enfim, há exceções. Nos últimos anos, o ICS vem desenvolven do um ensino ao nível de doutorado. É um dos pou- 
cos sítios, em Portugal, onde se pode ensinar, ao nível da pós-graduação, o que se está a fazer ao nível da pesquisa. Em uma universidade clássica, onde há uma grade curricular a ser cumprida, isso seria bem mais difícil.

Bem, há muitos portugueses que estudam na Universidade de São Paulo, na Universidade Federal do Rio de Faneiro, embora, como você já observou, quase todos estejam interessados em história moderna. Não podemos minimizar o fato de a interlocução entre Brasil e Portugal, nas áreas de história medieval e moderna, ter sido construída ao longo de décadas. Trata-se de fazê-la crescer e se diversificar. Nesse sentido, o CPDOC e o ICS acabam de assinar um acordo de cooperação, que facilita o acesso de estudantes portugueses à nossa documentação no Brasil, bem como a vinda de brasileiros que queiram trabalhar com temas contemporâneos em Portugal. De toda a forma, queríamos encerrar agradecendo, mais uma vez e muitíssimo, sua atenção e sua entrevista.

Notas

1. A Primeira República portuguesa compreende o período que vai da Revolução Republicana de 5 de outubro de 1910 ao golpe militar de 28 de maio de 1926. Predominantemente liberal e anticlerical, aprovou em 1911 uma Constituição que separava a Igreja do Estado e aprovava o divórcio, entre outras medidas. Trata-se de um período de grande instabilidade com mais de 40 governos e diversas tentativas de golpe de Estado. O Partido Democrático, originário de uma dissidência do Partido Republicano Português, foi predominante ao longo de todo o período. Fundado em 1912, teve como maior liderança o republicano histórico Afonso Costa. Cf. CATROGA, Fernando. O republicanismo em Portugal. (Lisboa: Editorial Notícias, 2000); MAGALHÃES, Joaquim Romero de. Vem aí a República! (Coimbra: Almedina, 2009); ROSAS, Fernando. Pensamento e acção política. (Lisboa: Editorial Notícias, 2004).
2. Golpe militar que pôs fim à Primeira República portuguesa e deu origem à ditadura salazarista. Dois anos após o início da ditadura militar o economista e professor da Universidade de Coimbra António Oliveira Salazar assume o cargo de ministro das Finanças. Aos poucos, à medida que consegue sanear as contas públicas, lidera o processo de transição da ditadura militar para uma ditadura civil e corporativa que tem início em 1932 e recebe o nome de Estado Novo. Cf. COSTA PINTO, António. O Estado Novo português e a vaga autoritária dos anos 1930 do século XX. In: COSTA PINTO, António \& MARTINHO, Francisco C. P. (Org.). O corporativismo em português. Estado, política e sociedade no salazarismo e no varguismo. (Rio de Janeiro: Civilização Brasileira, 2007), p. 17-43.

3. PCP - Partido Comunista Português. Fundado em 1921 a partir de egressos do 
movimento anarquista convertidos ao comunismo.

4. 25 de Abril de 1974: golpe de Estado liderado por oficiais médios, sobretudo capitães, das Forças Armadas portuguesas, desgastadas com o longo período de 13 anos de guerra colonial. A Revolução dos Cravos, como é denominado o 25 de Abril, foi responsável pela redemocratização portuguesa e a consequente reformulação partidária, de onde se origina o PS (Partido Socialista), fundado no exílio em 1973. Cf. LEITÃO, Nicolau. Estado Novo, democracia e Europa (1947-1986) (Lisboa: Imprensa de Ciências Sociais, 2007); LESTONBANDEIRA, Cristina. Da legislação à legitimação: o papel do Parlamento Português (Lisboa: Imprensa de Ciências Sociais, 2002); REZOLA, Maria Inácia. 25 de Abril: mitos de uma revolução (Lisboa: A Esfera dos Livros, 2007).

5. Marcelo José das Neves Alves Caetano (1906-1980). Advogado, jurista e historiador, ocupou diversos cargos no regime do Estado Novo, entre eles os ministérios das Colónias e da Presidência. Manteve-se afastado de qualquer cargo do regime entre 1958 e 1968, quando foi chamado a suceder Salazar na chefia do Executivo. Seu governo teve uma fase inicial chamada de "Primavera Marcelista" onde se esperava uma transição gradual para a democracia. Falhada a "Primavera", restou o crescimento da oposição até ao 25 de Abril de 1974. Exilou-se no Brasil, onde foi professor da Universidade Gama Filho e onde veio a falecer. ROSAS, Fernando \& OLIVEIRA, Pedro Ayres de (Organizadores). A transição falhada: o marcelismo e o fim do Estado Novo (Lisboa: Editorial Notícias, 2004); VALENTE, Vasco Pulido. Marcelo Caetano: as desventuras da razão (Lisboa: Alethéa, 2009).

6. Humberto da Silva Delgado. Militar português, foi adido militar junto à embaixada portuguesa em Washington e membro do comitê de representantes militares junto à Otan (Organização do Tratado do Atlântico Norte). A convite da oposição, candidatou-se à presidência da República nas eleições de 1958, cuja campanha de massas, com a realização de comícios por todo o país, foi inesperada para o regime. As consequências da campanha do chamado "general sem medo" não tardaram a aparecer, de modo que as regras eleitorais mudaram e tornaram-se mais restritivas nas eleições seguintes. Atraído para uma cilada organizada pela Pide (Polícia Internacional de Defesa do Estado), a polícia política do Estado Novo, foi assassinado em Badajoz, na Espanha, a 13 de fevereiro de 1965. DELGADO, Ivã, DELGADO, Humberto da Silva (1906-1965), ROSAS, Fernando \& BRITO, José Maria Brandão de (Organizadores). Dicionário de História do Estado Novo. Volume I: A - L (Lisboa: Círculo de Leitores, 1996), p. 252-254.

7. Mário Soares (1924) é filho do educador e ex-ministro da Primeira República João Soares. Formado em direito pela Universidade de Lisboa, tornou-se uma das principais referências da oposição civil ao salazarismo. Advogado de perseguidos políticos, foi obrigado a um exílio forçado em São Tomé. Quando da redemocratização ocupou os cargos de ministro dos Negócios Estrangeiros, de primeiro-ministro e de presidente da República. Cf. AVILEZ, Maria João. Mário Soares: ditadura e Revolução (Rio de Janeiro: Record, 1997).

8. Jorge Sampaio (1939). Advogado, foi militante da oposição desde a década de 1960, quando foi um dos expoentes da crise estudantil de 1962. Durante o Estado Novo notabilizou-se como advogado de perseguidos políticos. Na redemocratização ajudou a fundar o MES (Movimento de Esquerda Socialista). Em 1978 aderiu ao PS, ocupando diversos cargos, como o de deputado à Assembleia da República, presidente da Câmara de Lisboa e presidente da República. Cf. Museu da Presidência da República: www.museu.presid encia.pt 
9. Sobre a questão estudantil nos últimos anos do Estado Novo, ver: PROENÇA, Maria Cândida. A Reforma Educativa de Veiga Simão. In: ROSAS, Fernando \& OLIVEIRA, Pedro Ayres de (Coordenação). A transição falhada... op. cit, p. 233-261.

10. Editora ligada ao Partido Comunista Brasileiro (PCB).

11. Movimento Popular de Libertação de Angola. Organização de inspiração marxista-leninista, pró-soviética, que participou da luta anticolonial entre 1961 e 1974. Com o 25 de Abril e a redemocratização portuguesa o MPLA assumiu o poder em Angola, ainda que em luta contra agrupamentos apoiados pelos Estados Unidos e África do Sul, como a Unita (União Nacional para a Independência Total de Angola) e a FNLA (Frente Nacional para a Libertação de Angola). COSTA PINTO, António. O fim do Império português (Lisboa: Livros Horizonte, 2001).

12. Partido político de inspiração marxista-leninista pró China e Albânia. Disputava eleições sob a sigla UDP (União Democrática Popular). www.udp.pt

13. Diógenes Arruda Câmara (1914-1979). Militante do Partido Comunista Brasileiro (PCB), adere ao Partido Comunista do Brasil (PC do B) quando da crise sinosoviética. ROLLEMBERG, Denise. Exílio: entre raizes e radares (Rio de Janeiro: $\mathrm{Re}-$ cord, 1999); SALES, Jean Rodrigues. Da luta armada ao governo Lula: a história do Partido Comunista do Brasil (PC do B), in: REIS FILHO, Daniel Aarão e FERREIRA, Jorge (Organizadores). As esquerdas no Brasil. 3: Revolução e democracia (1964...) (Rio de Janeiro: Civilização Brasileira, 2007), p. 163-182.

14. António de Oliveira Salazar (18891970). Filho de uma família de pequenos proprietários e profundamente católica do conselho de Santa Comba Dão, ex-seminarista, formou-se em Direito pela Universi- dade de Coimbra e foi militante desde a juventude de organizações católicas, em particular o CADC (Centro Acadêmico de Democracia Cristã). Chamado a participar do governo da ditadura militar em 1928, logo liderou um processo de transição para uma ditadura civil de corte corporativo e conservador. Manteve-se no cargo de presidente do Conselho de Ministros do Estado Novo entre 1932 e 1968, quando foi substituído por Marcello Caetano devido a um acidente no qual bateu com a cabeça ao chão e em consequência ficou impossibilitado do exercício de qualquer função. Poucos dias depois entrou em estado coma e assim permaneceu até seu falecimento a 27 de julho de 1970. MENESES, Filipe Ribeiro de. Salazar: uma biografia política (3 edição. Lisboa: Dom Quixote, 2009).

15. O 25 de novembro de 1975 significa o retorno de Portugal à normalidade democrática após pouco mais de um ano e meio de turbulência revolucionária e indefinições quanto ao futuro institucional do país. Em resposta a uma tentativa de golpe dos setores mais radicalizados das Forças Armadas, dá-se um contra golpe sob a liderança de correntes civis e de militares moderados. VALENTE, Vasco Pulido. O " 25 de Abril", in Portugal: ensaios de história e de política (Lisboa: Alethéa, 2009), p. 279301.

16. Jorge Borges de Macedo (1921-1996). Historiador português, professor da Faculdade de Letras da Universidade de Lisboa, onde foi o diretor do Centro de História entre 1958 e 1973 . Ocupou também o cargo de diretor do Arquivo Nacional da Torre do Tombo entre 1990 e 1996. Cf. PEDREIRA, Jorge. Macedo, Jorge Borges de. In: Dicionário de História de Portugal (Coordenação de António Barreto e Maria Filomena Mónica) (Lisboa: Livraria Figueirinhas, 1999), p. 405.

17. Joaquim Barradas de Carvalho (19201980). Historiador português, professor cassado da Universidade de Lisboa, mi- 
litante do Partido Comunista Português, esteve exilado no Brasil com passaporte francês entre 1964 e 1974. Professor de História Ibérica do Departamento de História da USP, foi um dos principais introdutores no Brasil dos trabalhos de Braudel, Febvre e Soboul. Retornou a Portugal em seguida à Revolução dos Cravos e reassumiu a cadeira de professor da Universidade de Lisboa. Cf. MOTTA, Carlos Guilherme. Joaquim Barradas de Carvalho. Revista da Estudos Avançados. São Paulo: USP, 1994, p. 289-295.

18. António Borges Coelho (1928). Historiador medievalista português. Autor, entre outras obras, de História de Portugal (3 vols) (Lisboa: Caminho, 2011).

19. Nuno Monteiro. Historiador português. Autor, entre outros, de $O$ crepúsculo dos grandes. A casa e o patrimônio da aristocracia em Portugal (1750-1832) (Lisboa, Imprensa Nacional, Casa da Moeda, 2003) e D. Fosé I (Lisboa: Círculo de Leitores, 2006).

20. Bernardo Vasconcelos de Sousa. Historiador português. Autor, entre outros, de D. Afonso IV (Lisboa: Círculo de Leitores, 2005) e Ordens religiosas em Portugal: das origens a Trento (Lisboa: Livros Horizonte, 2006).

21. Pedro Tavares de Almeida. Historiador português. Autor, entre outros, de Eleições e caciquismo no Portugal oitocentista (Lisboa: Difel, 1991) e Perspectives of national e Elites on European citizenship: a south European view [codirecção de N. Conti e M. Cotta] (Londres: Routledge, 2011).

22. José Manuel Sobral. Historiador português. Investigador do Instituto de Ciências Sociais da Universidade de Lisboa. Autor, entre outros, de (1995), Memória e identidades sociais - dados de um estudo de caso num espaço rural português, in Análise Social, vol. XXX, 2. ${ }^{\circ}-3 .^{\circ}, 1995$, e Nações e nacionalismo: algumas teorias recentes sobre a sua génese e persistência na Europa ocidental e o caso português, in Inforgeo, 11, dezembro 1996, pp. 13-41.

23. Joaquim Veríssimo Serrão. Historiador português. Entre 1973 e 1974 foi reitor da Universidade de Lisboa. Cassado de suas funções quando do 25 de Abril, atuou na formação de instituições de ensino privado. Presidiu a Academia Portuguesa de História entre 1975 e 2006. Foi também sócio correspondente do Instituto Histórico e Geográfico Brasileiro. Cf. SERRÃO, Joaquim Veríssimo. Correspondência com Marcelo Caetano (1974-1980) (Lisboa: Bertrand, 1995).

24. Fernando Antônio Novaes (1933). Historiador brasileiro, professor aposentado da USP. Autor, entre outros, de Portugal e o Brasil na crise do Antigo Sistema Colonial (São Paulo: Hucitec, 1979).

25. Victorino Magalhães Godinho (19181911). Historiador português. Autor, entre outros, de Estrutura da antiga sociedade portuguesa (Lisboa: Arcádia, 1973); Os descobrimentos e a economia mundial (Lisboa: Presença, 1981) e $A$ expansão quatrocentista portuguesa (Lisboa: D. Quixote, 2008).

26. Miriam Halpern Pereira (1938). Historiadora portuguesa. Autora, entre outros, de Diversidade e assimetrias: Portugal nos séculos XIX e XX (Lisboa: Imprensa de Ciências Sociais, 2001); $O$ gosto pela história. Percursos de História Contemporânea (Lisboa: ICS, 2010). Entre 2001 e 2004 foi diretora do Arquivo Nacional da Torre do Tombo.

27. Adérito Sedas Nunes (1928-1991). Sociólogo e cientista político português, foi professor do ISCTE, da Universidade Nova de Lisboa e do Instituto de Ciências Sociais da Universidade de Lisboa, onde fundou a revista Análise Social. Foi também ministro da Coordenação Cultural e da Cultura e da Ciência durante o V Governo Constitucional (julho de 1979 a janeiro de 1980). Cf. MÓNICA, Maria Filomena. Antologia sociológica de Adérito Sedas Nunes 
(Lisboa: ICS, 2000) e NUNES, Adérito Sedas. A perspectiva sociocultural do desenvolvimento econômico. In: LAINS, Pedro \& FERREIRA, Nuno Estevão (Organizadores). Portugal em análise: antologia (Lisboa: ICS, 2007), p. 27-49.

28. COSTA PINTO, António. Os camisas azuis. Ideologia, elites e movimentos fascistas em Portugal (1914-1945) (Lisboa: Estampa, 1994).

29. Manuel Braga da Cruz (1946). Historiador português. Professor da Universidade Católica de Lisboa. Autor, entre outros, de Notas para uma caracterização política do Salazarismo. In: LAINS, P. \& PEREIRA, N. E (Organizadores). Portugal em análise: antologia (Lisboa: Imprensa de Ciências Sociais, 2007), p. 97-122; Transições históricas e reformas políticas em Portugal (Lisboa: Bizâncio, 1999), e O Estado Novoe a Igreja Católica (Lisboa: Bizâncio, 1998).

30. Manuel de Lucena. Historiador e cientista social português. Autor, entre outros, de Fascismo, colonialismo e revolução: uma leitura de Eduardo Lourenço. In: LAINS, P. \& PEREIRA, N. E (Organizadores). Portugal em análise: antologia (Lisboa: Imprensa de Ciências Sociais, 2007), p. 123-150; Uma leitura americana do cor- porativismo português. In: Análise Social. Revista do Instituto de Ciências Sociais da Universidade de Lisboa. V: XVII, $\mathrm{N}^{\circ} 60$, 1981, p. 415-434; A evolução do sistema corporativo português. Volume I: O Salazarismo (Lisboa: Perspectivas e realidades, 1976).

31. Philippe Schmitter (1936). Sociólogo norte-americano, professor do Instituto Universitário Europeu de Florença, autor, entre outros, de Portugal: do autoritarismo à democracia (Lisboa: Imprensa de Ciências Sociais, 1999).

32. Valentim Alexandre. Historiador português, autor, entre outros, de $O$ roubo das almas: Salazar, a Igreja e os totalitarismos (1930-1939) (Lisboa: Dom Quixote, 2006), e O Império Colonial. In: COSTA PINTO, A. (Coordenador). Portugal contemporâneo (Madrid: Sequitur, 2000), p. 39-60.

33. Cf. FIGUEIRA, António, COSTA PINTO, António \& SANDE, Paulo de Almeida (Coordenação). A União Europeia revisitada (Lisboa: Imprensa de Ciências Sociais, 2003) e COSTA PINTO, António \& TEIXEIRA, Nuno Severiano. A Europa do Sul e a construção da União Europeia (Lisboa: Imprensa de Ciências Sociais, 2005). 